Research Article

\title{
Kerja Sambilan Mempengaruhi Ketidakhadiran Pelajar Tingkatan 3
}

\section{Nurul Farhana Mat Daud ${ }^{1}$, Nur Asma Suzianti Mat Yusoff ${ }^{2}$, Nurul Hazlin Mohd Azmi ${ }^{3}$, Siti Zulaikha Khairunnisa Mohd Asri ${ }^{4}$, Nur Zalikha Manisha Zaidi ${ }^{2}$, Mohd Razimi Husin ${ }^{5}$}

${ }^{1}$ Fakulti Geografi, Universiti Pendidikan Sultan Idris. Perak, Malaysia.

${ }^{2}$ Fakulti Bahasa Melayu, Universiti Pendidikan Sultan Idris. Perak, Malaysia.

${ }^{3}$ Fakulti Ekonomi Rumah Tangga, UPSI. Perak, Malaysia.

${ }^{4}$ Fakulti Kimia, Universiti Pendidikan Sultan Idris. Perak, Malaysia.

${ }^{5}$ Fakulti Pembangunan Manusia, Universiti Pendidikan Sultan Idris. Perak, Malaysia.

Article History

Received:

20.07.2021

Revised:

07.08.2021

Accepted:

10.08.2021

*Corresponding Author:

Mohd Razimi Husin

Email:

razimi@fpm.upsi.edu.my

This is an open access article, licensed under: $\mathrm{CC}-\mathrm{BY}-\mathrm{SA}$
Abstrak: Gejala ponteng sekolah semakin hari semakin menular dalam kalangan pelajar di sekolah. Walaupun kita sudah mencapai era globalisasi, namun gejala ponteng ini amat sukar untuk diatasi. Oleh sebab yang demikian, satu kajian telah dijalankan terhadap masalah ponteng yang berlaku di sebuah Sekolah Menengah sekitar Kepong, Kuala Lumpur. Kajian ini bertujuan untuk mengenal pasti faktor kerja sambilan dan faktor lain punca pelajar ponteng sekolah. Selain itu, kajian ini juga dijalankan bertujuan untuk menghuraikan kesan-kesan gejala ponteng kepada pelajar dan sekolah serta menjelaskan langkah-langkah yang boleh diambil untuk mengurangkan gejala ponteng dan mengenalpasti tindakan yang diambil oleh pihak sekolah terhadap pelajar yang terlibat dalam gejala ponteng sekolah. Penyelidik menggunakan kaedah kajian temubual semi struktur bersama seorang responden yang merupakan guru disiplin di sekolah tersebut. Hasil kajian menunjukkan bahawa peringkat umur pelajar yang kerap ponteng adalah pelajar dari tingkatan 3. Dapatan kajian menunjukkan faktor utama pelajar ponteng ialah faktor kerja sambilan dan faktor sikap pelajar, faktor latar belakang, serta faktor rakan. Dapatan kajian juga menunjukkan bahawa peranan ibubapa, peranan sekolah serta peranan media massa merupakan langkah yang boleh diambil bagi mengatasi masalah tingkah laku ponteng sekolah.

Kata Kunci: Kerja Sambilan, Pelajar Tingkatan 3, Ponteng.

\section{Part -Time Work Affects Absenteeism the Student Form 3}

Abstract: Symptoms of skipping school are becoming more and more contagious among students at school. Although we have reached the era of globalization, but this symptom of skipping is very difficult to overcome. For this reason, a study was conducted on the problem of skipping that occurred in a Secondary School around Kepong, Kuala Lumpur. This study aims to identify the factors of part -time work and other factors that cause students to skip school. In addition, this study was also conducted to describe the effects of truancy symptoms to students and schools and explain the steps that can be taken to reduce truancy symptoms and identify actions taken by the school against students involved in truancy symptoms. The researcher used a semi structured interview research method with a respondent who is a discipline teacher in the school. The results showed that the age group of students who often skipped were students from Form 3. The findings showed that the main factors of students skipping were part -time work factors and student attitude factors, background factors, as well as peer factors. The findings also show that the role of parents, the role of the school and the role of the mass media are steps that can be taken to overcome the problem of skipping school behavior.

Keywords: Absenteeism, Part-Time Work, Student Form 3. 
Nurul Farhana Mat Daud, Nur Asma Suzianti Mat Yusoff, Nurul Hazlin Mohd Azmi, Siti Zulaikha Khairunnisa Mohd Asri, Nur Zalikha Manisha Zaidi, Mohd Razimi Husin.

Kerja Sambilan Mempengaruhi Ketidakhadiran Pelajar Tingkatan 3.

Journal of Humanities and Social Sciences, vol. 3, no. 2, pp. 67-79, August 2021. DOI: 10.36079/lamintang.jhass-0302.240

\section{Pengenalan}

Menurut Kamus Dewan Edisi Ketiga [1], kerja membawa urusan. Manakala sambilan bermaksud tidak kekal. Kerja sambilan pula bermaksud kerja yang dibuat disamping kerja biasa atau kerja tetap yang lain. Sebagai seorang pelajar tanggungjawab utama mereka adalah belajar dan menumpukan sepenuh perhatian terhadap akademik mereka. Bekerja sebenarnya bukanlah perkara yang wajib dilakukan oleh mereka, namun ramai dikalangan pelajar pada zaman ini lebih minat untuk bekerja terutama melakukan kerja sambilan. Hal ini dikatakan sedemikian kerana bagi pelajar apabila mereka melakukan kerja sambilan, mereka akan memperoleh gaji dan hal ini secara tidak langsung dapat menambahkan pendapatan mereka. Walaupun terdapat banyak kebaikan apabila pelajar melakukan kerja sambilan, namun terdapat juga keburukannya apabila pelajar tidak dapat menguruskan masa mereka antara bekerja dengan belajar. Hal ini dapat dikatakan sedemikian kerana di Sekolah Menengah Kebangsaan Kepong, para pelajar sanggup melakukan kegiatan ponteng sekolah hanya untuk bekerja.

Isu ponteng sekolah merupakan satu perkara yang penting untuk diberi perhatian. Pada masa kini, masalah disiplin seperti isu ponteng sekolah dalam kalangan pelajar sering berlaku sejak akhir-akhir ini walaupun pelbagai langkah telah diambil oleh semua pihak termasuk Kementerian Pelajaran Malaysia. Masalah ini semakin meningkat tahun demi tahun sehingga ada pelajar yang terlibat dengan kes jenayah berat bermula dari melakukan aktiviti ponteng. Isu ponteng juga merupakan salah satu masalah tingkah laku pelajar. Isu ponteng sekolah merupakan suatu isu yang tidak asing lagi kalangan pelajar di sekolah. Hal ini dikatakan sedemikian kerana aktiviti ponteng sekolah merupakan aktiviti yang menjadi trend dalam kalangan pelajar walaupun mereka mengetahui bahawa aktiviti ponteng yang dilakukan memberikan pelbagai risiko kepada diri mereka. Ponteng sekolah merupakan satu perbuatan salah laku dan dikategorikan dalam satu perbuatan yang menyalahi peraturan di sekolah.

Definisi ponteng sekolah boleh didefinisikan dalam pelbagai maksud. Menurut Yahya [2], menyatakan bahawa ponteng ialah tidak hadir ke sekolah tanpa sebab yang munasabah dan di luar pengetahuan ibu bapa atau penjaga. Walaupun begitu ada yang tidak hadir tetapi dalam pengetahuan ibu bapa. Ponteng didefinisikan sebagai perbuatan yang menjauhkan diri dari sekolah tanpa keizinan guru ataupun ibu bapa [2]. Masalah ponteng sekolah seharusnya diambil serius oleh pelbagai pihak kerana dengan melakukan aktiviti ponteng

sekolah dapat mempengaruhi seseorang pelajar untuk membuat perkara-perkara yang berisiko dan perbuatan yang tidak elok seperti terjebak dengan anasir-anasir jahat seperti kumpulan gangaster, kegiatan menagih dadah, mengedar dadah, terlibat dengan kegiatan mencuri dan merompak, menghisap rokok dan sebagainya.

Menurut Eing [3], menyatakan bahawa salah laku ponteng sekolah dapat dibahagikan kepada dua jenis iaitu ponteng sekolah berterusan dan ponteng sekolah secara berkala. Ponteng sekolah berterusan dapat ditakrifkan sebagai ketidakhadiran murid ke sekolah tanpa kebenaran secara berturut-turut untuk suatu tempoh masa. Eing [3] menyatakan bahawa ponteng sekolah berkala ditakrifkan sebagai ketidakhadiran murid ke sekolah tanpa kebenaran untuk suatu tempoh yang berturut-turut. Ponteng sekolah berkala terdiri daripada murid yang tidak datang ke sekolah dalam tempoh masa sehari dan dua hari berikutnya. Kesalahan ponteng sekolah jenis ini paling kerap dilakukan oleh pelajar yang sering ponteng sekolah.

Masalah ponteng sekolah selalunya berlaku kepada pelajar yang belajar di sekolah menengah dan pelajar yang berada di kedudukan menengah atas. Hal ini berlaku sedemikian kerana, menurut Erik Erikson menyatakan bahawa pada peringkat umur ini, pelajar mengalami fasa identiti lawan kekeliruan identiti. Fasa ini berlaku pada kanak-kanak yang sudah meningkat remaja. Mereka mula dan sentiasa mencari identiti diri sama ada dalam personaliti, bidang pekerjaan, perasaan jantina, politik dan agama. Pada peringkat ini, mereka keliru terhadap identiti diri seterusnya mudah terikut dan terpengaruh terutamanya persekitaran sosial mereka. Dalam isu ponteng ini pengaruh rakan-rakan menjadikan mereka mudah terikut untuk melakukan aktiviti ponteng. Selain itu, pelajar yang berada di sekolah menengah juga melakukan aktiviti ponteng kerana mereka merasakan diri mereka sudah tua dan bebas melakukan apa sahaja yang diinginkan oleh mereka.

Seharusnya isu ponteng ini harus diambil perhatian oleh semua pihak. Masalah ponteng di sekolah ini penting untuk diatasi kerana masalah ponteng merupakan faktor terjadinya masalah jenayah dalam kalangan pelajar. Perkara ini amat membimbangkan kerana bagi melahirkan asset negara yang berguna kepada pembangunan dan keselamatan negara, isu ini perlu diatasi. Semua pihak yang terdiri daripada pihak sekolah, ibu bapa, komuniti serta pelbagai pihak yang berkaitan perlulah mengambil berat 
Nurul Farhana Mat Daud, Nur Asma Suzianti Mat Yusoff, Nurul Hazlin Mohd Azmi, Siti Zulaikha Khairunnisa Mohd Asri, Nur Zalikha Manisha Zaidi, Mohd

berkaitan isu ponteng sekolah ini. Pelbagai inisiatif hendaklah dilakukan bagi mengurangkan masalah ponteng sekolah bagi melahirkan pelajar yang cemerlang dari pelbagai aspek sesuai dengan Falsafah Pendidikan

Negara iaitu bagi suatu usaha berterusan ke arah memperkembangkan lagi potensi individu secara menyeluruh dan bersepadu untuk mewujudkan insan yang seimbang dan harmonis dari segi intelek, rohani, emosi dan jasmani.

Tujuan kajian ini adalah menjelaskan faktor kerja sambilan dan faktor lain punca pelajar ponteng sekolah, menghuraikan kesan-kesan gejala ponteng kepada pelajar dan sekolah, menjelaskan langkahlangkah yang boleh diambil untuk mengurangkan gejala ponteng dan mengenalpasti tindakan yang diambil oleh pihak sekolah terhadap pelajar yang terlibat dalam gejala ponteng sekolah.

\section{Kajian Literature}

Kajian literatur adalah rujukan secara kritikal dan sistematik mengenai maklumat terpilih bagi membuktikan bahawa teori yang digunakan bukanlah sekadar rekaan. Di dalam sorotan literature ini mengandungi pernyataan, kaedah, teori, pendapat, penilaian dan laporan kajian berkenaan tajuk yang dipilih oleh pengkaji. Sumber yang digunakan diambil daripada jurnal, jurnal atas talian, artikel atas talian dan kenyataan masalah daripada pakar.

Trend ponteng sekolah semakin menjadi-jadi saban hari melibatkatkan pelajar sekolah rendah dan sekolah menengah. Masalah ini telah lama diperkatakan dan dibincangkan di setiap intstitusi pendidikan seluruh negara. Menurut artikel akhbar digital tempatan, masalah ponteng sekolah tersenarai dalam lima masalah disiplin utama yang dilakukan pelajar dan negeri Selangor telah mencatatkan bilangan murid antara paling ramai di negara ini iaitu sehingga 27 Januari 2019, sebanyak 894266 murid melibatkan sekolah menengah dan rendah telah didaftarkan terlibat dalam kes ponteng sekolah. Hal ini jelaslah bahawa masalah tingkah laku ponteng sekolah kini tidak asing lagi di mata masyarakat dan negara.

Menurut Yahya et al. [4] dan Amin et al. [5] menjelaskan bahawa ponteng terdiri daripada empat jenis. Jenis yang pertama ialah ponteng sekolah, di mana pelajar yang melakukan masalah ponteng sekolah ini biasanya akan keluar dari rumah dengan memakai pakaian seragam sekolah tetapi mereka tidak sampai ke sekolah. Malahan, terdapat sesetengah daripada mereka yang berkeliaran dan melepak di pusat beli belah, kedai siber dan di rumah-rumah kosong yang agak terpencil. Masalah ini menjadi kian meruncing apabila pelajar yang terlibat dengan gejala ponteng sekolah mudah terjebak dengan gejala negatif yang lain seperti merokok, mengambil dadah dan vandalisme. Oleh itu, tanggungjawab ibu bapa amat penting dalam memastikan pelajar tidak terjebak dengan masalah tingkah laku ponteng sekolah dan sentiasa mengawasi tingkah laku anak-anak di rumah.

Dalam kajian ini, penekanan diberikan terhadap faktor kerja sambilan merupakan asbab peningkatan kadar ponteng dalam kalangan pelajar tingkatan tiga di lokasi sekolah tersebut. Hal ini disebabkan oleh faktor sosioekonomi keluarga yang rendah dan perbelanjaan yang tinggi diperlukan untuk menampung kehidupan mendorong pelajar sekolah untuk bekerja sewaktu persekolahan berlangsung. Hal ini kerana, kajian mendapati bahawa kebanyakan pelajar yang terlibat dengan ponteng sekolah sekolah datangnya dari sekolah-sekolah yang terletak dipinggir bandar. Pelajarpelajar yang tinggal dipinggir bandar seringkali menghadapi masalah dari segi persekitaran tempat tinggal, status sosioekonomi keluarga dan pergaulan antara rakan-rakan. Kebanyakan ibu bapa mereka berpendapatan rendah dan tidak dapat menyediakan perbelanjaan yang mencukupi untuk menampung bilangan anak yang ramai. Jadi, untuk meringankan bebabna yang ditanggung oleh ibu bapa mereka, ada pelajar yang sanggup berhenti sekolah dan bekerja bagi mendapatkan wang perbelanjaan harian mereka [6].

Selain itu, kajian ini juga mendapati bahawa terdapat beberapa faktor lain menyebabkan berlakunya masalah tingkah laku ponteng sekolah dalam kalangan pelajar iaitu menurut kajian yang dilakukan oleh Dr. Amirah Latif dan Dr. Adillah Syazwani Khairi, dua orang pensyarah di Universiti Malaya yang mengakaji punca pelajar ponteng di beberapa buah sekolah di sekitar Lembah Klang mendapati dalam kajian melibatkan 125 orang pelajar yang ponteng sekolah, hanya 10 orang pelajar yang menyatakan bahawa mereka bosan dengan cara pengajaran guru. Yang lain-lain menyatakan bahawa mereka ponteng kerana kurangnya minat untuk belajar, suka mengikuti kawan-kawan dan tidak kurang juga melakukan kerja sambilan [7].

Teori yang jelas membincangkan faktor utama berlakunya ponteng sekolah dalam kalangan pelajar sekolah adalah Teori Maslow. Teori Maslow atau dikenali teori hierarki keperluan Maslow yang telah 
dikemukan olehnya pada tahun 1943. Teori ini mengandungi lima peringkat keperluan manusia iaitu; pertama, keperluan asas; kedua, keperluan keselamatan dan jaminan diri; ketiga, keperluan untuk berkasih sayang; keempat, keperluan untuk penghormatan diri; dan yang terakhir iailah keperluan untuk pencapaian diri. Menurut Malsow [8], tingkat memenuhi keperluan diri ini adalah mengikut susunan secara hierarki. Untuk memenuhi satu hierarki keperluan di atas, seseorang perlu memenuhi hierarki keperluan yang terdahulu. Ini bermakna, seseorang itu tidak mungkin dapat memenuhi keperluan di tingkat atas terlebih dahulu tanpa memenuhi tingkat keperluan di bawah [9]. Dalam konteks kajian ini, faktor kerja sambilan boleh dikaitkan dengan susunan hierarki pertama iaitu keperluan asas. Sebagai contoh, pelajar perlu bekerja sambilan untuk mendapatkan wang perbelanjaan untuk keperluan asas kerana kekawangan kewangan dalam sosioekonomi keluarga sehingga menyebabkan mereka terpaksa ponteng sekolah. Jelaslah bahawa teori Maslow mempunyai perkaitan dengan faktor kerja sambilan menyebabkan pelajar terlibat dalam gejala ponteng sekolah.

Seterusnya, teori lain yang digunakan adalah teori konsep kendiri yang dipelopori oleh Rogers (1940) iaitu mengenai organisme dan kendiri manusia. Organisme adalah pusat segala pengalaman yang melibatkan kesedaran bagi sesuatu masa. Terdapat pengalaman yang tidak realistik. Pengalaman yang tidak diuji ini boleh membuatkan dia bertingkah laku dengan tidak realistik atau merosakkan dirinya sendiri. Dalam kes ini, Rogers percaya remaja yang mengalami masalah dan melakukan aktiviti tingkah laku boleh dididik oleh ibu bapa dengan memberikan perhatian kepada perbualan anak-anak remaja. Di samping itu, setiap pendapat yang baik perlu diberi penghormatan oleh ibu bapa. Salah satu prinsip teori konsep kendiri ialah ibu bapa dan guru perlu mengadakan perhubungan mesra dengan pelajar. Apabila hubungan yang rapat diwujudkan pelajar dapat meluahkan isi hati kepada mereka [10]. Oleh itu, penglibatan ibu bapa dirumah merupakan langkah utama dalam membendung masalah ponteng dalam kalangan pelajar sekolah.

Satu lagi teori menerangkan tentang tingkah laku berkaitan dengan pelajar ponteng sekolah adalah Teori Pembelajaran Sosial oleh Bandura [11]. Menurut beliau individu bertingkah laku berdasarkan pengalaman melihat orang lain sebagai model dan bukanlah wujud secara semula jadi. Teori ini menekankan faktor kelakuan pelajar itu sendiri, pengaruh persekitaran dan interaksi kognitif mempengaruhi tingkah laku pelajar remaja. Teori pembelajaran sosial juga menekankan tentang kepentingan penilaian kognitif dan emosi. Teori ini memperlihatkan pengaruh sosial ke atas personaliti remaja dalam mempengaruhi tingkah laku seseorang. Dalam aspek ini, remaja di bangku sekolah daripada pelbagai latar belakang perlu dilihat secara berbeza kerana mereka telah melalui pelbagai pengalaman hidup. Remaja ini telah menjadikan individu-individu lain sebagai model tanpa mereka sedari. Maka wujudlah pelbagai tingkah laku yang menimbulkan pelbagai masalah disiplin di sekolah lebih-lebih lagi masalah tingkah laku ponteng sekolah [12].

Kesimpulannya, masalah tingkah laku ponteng sekolah telah menjadi bahan kritikan dan kajian oleh pelbagai pihak pengkaji tempatan dalam mengkaji punca dan solusi bagi menangani masalah tersebut. Justeru, pihak sekolah dan Kementerian Pelajaran Malaysia (KPM) telah melahirkan beberapa inisiatif bagi membendung masalah tingkah laku ponteng sekolah. Oleh itu, bagi menyokong kajian yang dilakukan oleh pengkaji tempatan, kajian tentang kerja sambilan mempengaruhi pelajar tingkatan 3 ponteng sekolah di Sekolah Menengah Kebangsaan Kepong telah dilakukan bagi membantu mendapatkan maklumat berkaitan dengan isu yang dibincangkan dengan lebih terperinci.

\section{Metodologi Kajian}

Metodologi merupakan satu set kaedah yang digunakan untuk menjalankan kajian ke atas subjek kajian yang tertentu. Dalam bahagian ini terdapat dua kaedah yang telah digunakan iaitu melibatkan kaedah temubual dan kaedah rujukan internet bagi mendapatkan data dan maklumat berkaitan dengan masalah ponteng sekolah dalam kalangan pelajar.

\subsection{Kaedah Temu Bual Semi Struktur}

Kaedah pertama yang digunakan dalam kajian ini adalah kaedah temu bual. Ia dijalankan bagi mendapatkan maklumat berkaitan dengan masalah ponteng sekolah. Temu bual ini telah dibuat secara atas talian dengan menggunakan "Google Meet" iaitu kami telah mengadakan temu bual bersama seorang guru disiplin yang berpengalaman. Untuk menjalankan temubual ini kami telah membina lima soalan. Kami telah mengajurkan soalan-soalan tersebut kepada guru disipilin. Berdasarkan maklumat yang diberikan oleh guru disiplin tersebut kami telah mengemukakan soalan tambahan bagi mendapatkan maklumat secara lebih mendalam. 
Nurul Farhana Mat Daud, Nur Asma Suzianti Mat Yusoff, Nurul Hazlin Mohd Azmi, Siti Zulaikha Khairunnisa Mohd Asri, Nur Zalikha Manisha Zaidi, Mohd Razimi Husin.

Kerja Sambilan Mempengaruhi Ketidakhadiran Pelajar Tingkatan 3.

Journal of Humanities and Social Sciences, vol. 3, no. 2, pp. 67-79, August 2021. DOI: 10.36079/lamintang.jhass-0302.240

\subsection{Kaedah Rujukan Internet}

Selain daripada kaedah temubual kami juga telah menggunakan kaedah rujukan internet bagi mencari maklumat tambahan berkaitan dengan masalah ponteng sekolah. Kaedah rujukan internet ini adalah melalui buku atas talian atau jurnal. Dengan adanya rujukan internet ini dapat membantu untuk menyiapkan tugasan ini dengan lebih mudah dan berkesan.

\subsection{Lokasi Kajian}

Kajian ini telah dijalankan di Sekolah Menengah Kebangsaan Kepong. Hal ini adalah, bagi mendapatkan maklumat berkaitan dengan pelajar sekolah tersebut yang terlibat dengan masalah ponteng sekolah. Disebabkan, isu covid 19 yang kian meningkat di negara kita terutamanya di daerah kajian kami, kami terpaksa akur dengan Perintah Kawalan Pergerakan yang telah ditetapkan. Jadi bagi menyempurnakan kajian ini kami telah menjalankan kajian dengan mengadakan temu bual secara atas talian iaitu dengan menggunakan "Google Meet" bersama seorang guru disiplin di sekolah tersebut.

\section{Dapatan Kajian}

Di bahagian ini, kami akan membincangkan dapatan kajian berdasarkan temu bual yang dikalankan tentang masalah ponteng sekolah di Sekolah Menengah Kebangsaan Kepong.

\subsection{Demografi Sampel}

Kami memilih seorang guru disiplin di sebuah Sekolah Menengah sekitar Kepong, Malaysia. Beliau bernama Wanie Samad (Nama Samaran). Beliau berumur 30 tahun dan berpengalaman mengajar selama 5 tahun. Sekolah tersebut mempunyai dua sesi persekolahan iaitu sesi petang untuk tingkatan 1 dan 2 dan sesi pagi untuk pelajar tingkatan 3, 4 dan 5. Beliau mendapat kelulusan Ijazah Sarjana Muda Pendidikan Moral di Universiti Putra Malaysia. Beliau merupakan salah seorang guru disiplin semasa sesi persekolahan pada sesi pagi. Oleh sebab yang demikian, banyak maklumat dan data berkaita pelajar yang ponteng kami dapat perolehi. Di samping itu, beliau juga merupakan seorang guru disiplin yang berpengalaman dan tegas dalam menjalankan tugas.

\subsection{Peringkat Umur Pelajar Yang Sering Melakukan Masalah Ponteng di SMK Kepong}

Secara umumnya, ponteng sekolah membawa maksud ketidakhadiran pelajar ke sekolah tanpa pengetahuan ibu bapa dengan alasan yang tidak bermunasabah. Dewasa kini, ponteng sekolah menjadi trend dalam kalangan pelajar di sekolah. Ponteng sekolah terjadi dalam kalangan pelajar sekolah rendah dan sekolah menengah. Masalah ponteng sekolah ini juga kerap berlaku tidak mengira peringkat umur para pelajar. Umumnya peringkat umur pelajar semakin meningkat menggalakkan lagi perubahan dalam diri mereka terutamanya untuk mencuba benda yang baru. Pelajar yang berumur tiga belas hingga enam belas tahun kebiasaanya sering melakukan aktiviti ponteng sekolah. Hal ini bertepatan dengan kajian yang telah dijalankan melalui temubual bersama responden iaitu peringkat umur pelajar yang sering melakukan masalah atau aktiviti ponteng sekolah ialah pelajar yang berumur lima belas tahun yang merupakan pelajar tingkatan 3 . Walaupun seharusnya pelajar ini harus lebih menumpukan masa untuk membuat persiapan bagi menghadapi Peperiksaan Penilaian Tingkatan 3 (PT3), namun terdapat segelintir pelajar yang masih terjebak dengan isu ponteng sekolah.

Melalui temubual yang telah kami jalankan, responden mengatakan bahawa di Sekolah Menengah Kebangsaan Kepong kadar ponteng di sekolah tersebut adalah tidak mengira umur yang bermaksud pelajar dari tingkatan 1 hingga tingkatan 6, terdapat hanya sebilangan kecil yang melakukan aktiviti ponteng pada sesi pagi. Hal ini disebabkan oleh beliau hanya memperolehi data kadar pelajar yang ponteng sekolah pada sesi pagi sahaja kerana responden merupakan guru disiplin pada sesi persekolahan pada sesi pagi sahaja.

"Berdasarkan pengalaman saya, kes ponteng yang paling berat ni tingkatan 3. Tingkatan 3 hanya seorang sahaja. Dia yang selalunya ponteng kerana dia seorang yang tidak minat belajar dan merupakan seorang yang suka bekerja jadi dia tipu mak ayah dia dia datang ke sekolah sedangkan dia keluar pergi kerja. Kalau tingkatan 4, mereka juga ramai yang ponteng kerana mereka rasa mereka dah besar dan semakin matang. Sifat ingin mencuba dan pengaruh kawan mempengaruhi mereka. Tingkatan 3 dan tingkatan 4 biasanya kerap ponteng. Kalau tingkatan 5 mereka dah kurang ponteng kerana mereka 
Nurul Farhana Mat Daud, Nur Asma Suzianti Mat Yusoff, Nurul Hazlin Mohd Azmi, Siti Zulaikha Khairunnisa Mohd Asri, Nur Zalikha Manisha Zaidi, Mohd

dah dapat kesedaran nak menghadapi peperiksaan. Kalau mengikut statisktik ponteng SMK Kepong, tingkatan 3 dan tingkatan 4 yang paling ramai ponteng. ”kata responden.

Namun responden juga mengatakan bahawa sepanjang pengalaman beliau menjadi guru disiplin terutamanya pada sesi pagi persekolahan, pelajar yang sering ponteng sekolah ialah seorang pelajar dari tingkatan 3. Hanya seorang pelajar yang sama sahaja yang sering melakukan aktiviti ponteng sekolah. Menurut responden, pelajar tersebut selalu ponteng kerana pelajar tersebut merupakan seorang pelajar yang tidak minat belajar dan merupakan seorang yang suka bekerja menyebabkan beliau sanggup menipu ibu bapanya bahawasanya dia datang ke sekolah akan tetapi sebenarnya pelajar tersebut tidak hadir ke sekolah kerana ingin bekerja.

\subsection{Faktor Berlakunya Gejala Ponteng di SMK Kepong}

Menurut temubual yang telah dijalankan dengan responden, terdapat beberapa faktor berlakunya gejala ponteng di SMK Kepong. Antaranya ialah:

\section{Kerja Sambilan}

Menurut Ali et al. [13], menyatakan bahawa terdapat pelajar yang terpaksa bekerja untuk menampong kewangan keluarga kerana kemiskinan, dan ramai juga pelajar terdorong bekerja untuk membeli peralatan moden (telefon bimbit, baju berjenama, top-up dll) untuk gaya hidup semasa, dan paling serius ialah mereka kurang fokus terhadap pelajaran. Justeru, fenomena pelajar bekerja sambilan dibimbangi menggugat pendidikan [14]. Faktor kerja sambilan mempengaruhi murid tingkatan 3 di situ melakukan tingkah laku ponteng dan ini merupakan faktor utama. Hal ini dikatakan sedemikian kerana menurut temubual yang dijalankan bersama responden, beliau mengatakan bahawa suka bekerja sambilan merupakan faktor utama. Seperti yang dinyatakan oleh responden:

"Dia yang selalunya ponteng kerana dia seorang yang tidak minat belajar dan merupakan seorang yang suka bekerja jadi dia tipu mak ayah dia dia datang ke sekolah sedangkan dia keluar pergi kerja," kata responden.

Beliau juga mengatakan bahawa ramai pelajar di situ yang bekerja. Oleh sebab yang demikian, sewaktu mereka datang ke sekolah mereka akan merasa letih, merasa sangat mengantuk dan penat.

"Sebagai contoh di sekolah tersebut murid ramai bekerja. Jadi sewaktu mereka datang ke sekolah mereka merasa sangat mengantuk dan penat. Sebab itu dia ponteng," kata responden.

Oleh itu mereka mengambil jalan mudah dengan melakukan aktiviti ponteng sekolah. Hal ini jelas menunjukkan kurangnya semangat ingin belajar dalam diri mereka. Mereka seolah-olah tidak mempunyai motivasi untuk belajar dan mereka lebih rela tidur daripada bangun awal pagi untuk ke sekolah bagi melepaskan penat mereka.

\section{Sikap Pelajar}

Selain itu, semasa temubual dijalankan juga responden ada mengatakan bahawa sikap pelajar yang ingin mencuba benda baru juga mempengaruhi diri mereka untuk melakukan aktiviti ponteng sekolah. Menurut responden, pelajar dari tingkatan 1 dan tingkatan 2 menunjukkan sikap mereka ingin mencuba benda baru.

"Dia berkawan. Bila dia berkawan, kawan dia kata hari ini dia nak keluar pergi, contoh kalau sekolah ini dekat dengan Selayang Mall. Kita pergi Selayang Mall. Mereka ramai-ramai ponteng pergi sana dan remaja ataupun pelajar tingkatan 1 dan 2, dia baru rasa bebas daripada sekolah rendah. Masa ini lah mereka baru cuba nak meneroka dunia ini dan sikap ingin mencuba dia tu menyebabkan dia rasa biarlah tak pergi sekolah, jom kita pergi sini-sini sebab satu dari segi sikap diri sendiri, " kata responden.

Hal ini dikatakan sedemikian kerana pelajar dari tingkatan 1 dan tingkatan 2 ini merasakan diri mereka bebas dari sekolah rendah dan mengambil peluang yang ada dengan melakukan masalah 
ponteng sekolah. Bagi mereka pada masa itulah mereka dapat mencuba benda baharu dan menerokainya sehinggakan mereka merasakan kehadiran ke sekolah adalah perkara yang tidak penting.

Seterusnya, responden juga menyatakan bahawa sikap pelajar yang tidak berminat untuk pergi ke sekolah juga menyebabkan pelajar itu sering ponteng. Menurut Rashid [14], menyatakaan bahawa sikap pelajar yang tiada minat untuk ke sekolah, tiada motivasi untuk ke sekolah dan tiada kesedaran betapa pentingnya ilmu pengetahuan merupakan faktor berlakunya masalah ponteng di sekolah. Tidak minat untuk belajar dan memahami apa yang diajar oleh guru menggalakan mereka untuk ponteng.

"ketiga dari segi sikap dia sendiri yang memang malas. Mungkin sebab sekolah saya ini ramai Cina. Bila dia datang sekolah, cikgu- cikgu kan Melayu. Jadi, dia macam tak faham sangat cikgu bercakap bahasa Melayu dan menyebabkan dia rasa bosan nak belajar. Bila dia rasa bosan, dia tak seronok nak belajar dan juga salah satu faktor lah dia tu ponteng. Ponteng kelas mungkin dia tak suka cikgu-cikgu ini dia ponteng, dia ponteng sekolah, ponteng kelas sebab, dia tak seronok, dia memang tak suka belajar," kata responden.

Sebagai contoh, responden ada mengatakan di sekolah menengah kebaangsaan kepong terdapat ramai pelajar yang terdiri daripada pelajar berbangsa Cina dan bagi beliau ini merupakan faktor utama. Hal ini kerana, apabila guru sedang mengajar di dalam kelas, guru- guru lebih banyak menggunakan bahasa melayu menyebabkan pelajar- pelajar berbangsa cina tidak memahami apa yang diajar dan secara tidak langsung mereka menjadi bosan dan seterunya tidak minat untuk belajat. Ini menggalakkan lagi mereka tidak hadir ke sekolah. Menurut responden lagi, beliau mengatakan bahawa sikap pelajar tidak meminati guru yang mengajar, tidak meminati subjek yang diajar oleh guru serta ponteng secara sengaja juga menjadi faktor mereka ponteng sekolah.

\section{Faktor Latar Belakang}

Menurut Yahya [2], menyatakan bahawa kecelaruan dalam kelaurga dan kurang perhatian ibu bapa adalah punca kuat yang mempengaruhi jiwa remaja. Hal ini bertepatan dengan faktor berlakunya ponteng dalam kalangan pelajar kerana faktor latar belakang keluarga menjadi faktor yang kuat untuk menggalakkkan seseorang pelajar melakukan masalah ponteng sekolah. Perasaan tertekan dengan masalah keluarga seperti ibu bapa bercerai mempengaruhi mereka untuk cenderung melakukan aktiviti ponteng sekolah. Menurut Bakar [15], dalam kajiannya menyatakan bahawa proses didikan atau proses sosialisasi yang diterima oleh pelajar sejak kecil dalam keluarga berpengaruh kepada tingkah laku mereka. Hal ini bertepatan dengan faktor pelajar melakukan masalah tingkah laku seperti masalah ponteng sekolah kurana kurangnya didikan oleh ibu bapa disebabkan oleh latar belakang keluarga yang bermasalah.

"Keluarga yang bermasalah juga menjadikan kesan ataupun impak kepada murid itu sendiri. Saya pernah panggil beberapa orang pelajar saya yang ponteng. Saya tanyalah kenapa awak ponteng dan dia mengatakan dia sangat stress dekat rumah, sebab mak ayah bercerai, mak ayah bergaduh. Jadi apabila dia datang ke sekolah dia tidak boleh hendak fokus. Yangni bukan sahaja pelajar kelas belakang tetapi pelajar kelas depan pun ponteng sebab latar belakang kelaurga yang bermasalah," kata responden. "Bila keluarga bermasalah dia memang tak seronok nak datang sekolah sebab tu berlakunya masalah ponteng," kata responden.

Menurut temubual yang telah dijalankan dengan responden, didapati bahawa keluarga yang bermasalah juga menjadikan kesan ataupun impak kepada murid itu sendiri untuk melakukan aktiviti ponteng sekolah. Responden juga mengatakan bahawa beliau pernah memanggil pelajar yang ponteng sekolah dan bertanya mengapa pelajar tersebut ponteng dan beliau mengatakan pelajar tersebut ponteng kerana ibu bapa mereka telah bercerai dan ada juga pelajar yang mengatakan ibu bapa mereka sering bertengkar dan bergaduh apabia berada di rumah. Apabila pelajar tersebut datang ke sekolah, pelajar tersebut tidak boleh menumpukan perhatian semasa sesi pembelajaran di dalam kelas. Menurut responden lagi, beliau mengatakan bahawa pelajar yang menghadapi tekanan masalah keluarga ini tidak mengira kepandaian pelajar dimana pelajar yang berada di kelas hadapan juga 
Nurul Farhana Mat Daud, Nur Asma Suzianti Mat Yusoff, Nurul Hazlin Mohd Azmi, Siti Zulaikha Khairunnisa Mohd Asri, Nur Zalikha Manisha Zaidi, Mohd Razimi Husin.

Kerja Sambilan Mempengaruhi Ketidakhadiran Pelajar Tingkatan 3.

Journal of Humanities and Social Sciences, vol. 3, no. 2, pp. 67-79, August 2021. DOI: 10.36079/lamintang.jhass-0302.240

melakukan masalah ponteng sekolah kerana latar belakang keluarga mereka yang bermasalah.

\section{Faktor Rakan Sebaya}

Rakan sebaya merupakan remaja yang sama umur ataupun remaja yang mempunyai paras kematangan yang sama. Rakan sebaya juga berpengaruh untuk membentuk akhlak dan peribadi seseorang remaja. Menurut Bakar [15], dalam kajiannya menyatakan bahawa pada tahap peringkat umur yang muda ini, remaja masih mentah, nalurinya kurang tabah dan sifat ingin mencuba itu mudah berkobar-kobar. Jadi apabila dipujuk atau dipengaruhi oleh rakan-rakan sebaya, mereka sudah tentu tidak dapat mengawal perasaannya untuk turut terlibat dalam gejala negatif [14]. Selain itu, rakan sebaya juga merupakan individu yang paling hampir dengan pelajar dan semua masalah yang dihadapi oleh pelajar sering diluahkan kepada rakan sebaya menyebabkan mereka menjadi lebih rapat dan mempengaruhi mereka untuk sentiasa melakukan perkara bersama-sama atas alasan rakan sebaya memahami jiwa mereka lebih daripada keluarga sendiri.

"Yang kedua, disebabkan pengaruh rakan sebaya. Rakan sebaya ini memang sangatsangat mempengaruhi. Dia berkawan. Bila dia berkawan, kawan dia kata hari ini dia nak keluar pergi, contoh kalau sekolah ini dekat dengan Selayang Mall. Kita pergi Selayang Mall. Mereka ramai-ramai ponteng pergi sana dan remaja ataupun pelajar tingkatan 1 dan 2, dia baru rasa bebas daripada sekolah rendah," kata responden.

Hal ini bersesuaian dengan temubual yang telah djalankan oleh responden. Responden mengatakan bahawa faktor rakan sebaya ini memang sangat mempengaruhi seseorang pelajar untuk ponteng sekolah. Sebagai contoh, Sekolah Menengah Kebangsaan Kepong merupakan sekolah yang dekat jaraknya dengan Selayang Mall. Jadi, sekumpulan sekumplan pelajar yang terdiri daripada tingkatan 1 dan tingkatan 2 melakukan aktiviti ponteng sekolah beramai-ramai untuk pergi ke pusat membeli belah tersebut. Pengaruh rakan sebaya yang kuat untuk melakukan aktiviti ponteng sekolah menyebabkan mereka mudah terikut dan untuk menjaga hati rakan-rakan mereka. Selain itu, rakan sebaya juga merupakan individu yang paling hampir dengan pelajar dan semua masalah yang dihadapi oleh pelajar sering diluahkan kepada rakan sebaya menyebabkan mereka menjadi lebih rapat dan mempengaruhi mereka untuk sentiasa melakukan perkara bersama- sama atas alasan rakan sebaya memahami jiwa mereka lebih daripada keluarga sendiri. Tujuan pelajar sekolah ponteng sekolah dengan pergi ke pusat membeli belah juga adalah untuk melepak bersama rakan rakan.

\subsection{Langkah Mengatasi Masalah Ponteng Sekolah}

Langkah yang boleh diambil bagi mengatasi masalah tingkah laku ponteng sekolah, ialah:

\section{Peranan Ibu Bapa}

Bak kata pepatah Melayu, 'melentur buluh biarlah dari rebungnya' kerana anak-anak diibaratkan kain putih yang dicorakkan oleh ibu bapa mereka. Jadi terpulanglah kepada ibu bapa untuk mencorakkan kehidupan anak-anak mereka menuju kepada kebaikan ataupun sebaliknya. Menurut Rahman \& Ibrahim [16], ibu bapa merupakan orang yang memainkan peranan penting dalam pembentukan peribadi anak-anak. Didikkan awal yang sempurna boleh menjamin kejayaan anak-anak di masa hadapan agar tidak terjebak atau terjerumus kepada perkara-perkara atau perbuatan-perbuatan yang negatif.

'Dari segi ibu bapa pertamanya ibu bapa sendiri perlulah memberi perhatian, 'follow up' dengan anak-anak. Maknanya, setiap hari balik sekolah kena tanya anakanak macam mana pembelajaran di sekolah dan tidak mengabaikan anak-anak. Kalau sikap ibu bapa sendiri yang mengabaikan anak-anak, mereka akan lebih seronok. Budak bukannya suka belajar. Kalau ibu bapa yang sambil lewa, maknanya anak- anakpun buat tidak cakna. Jadi, ibu bapa sendiri perlu beri perhatian, 'follow up' masalah pembelajaran anak-anak dekat sekolah, " kata responden.

Menurut responden, peranan ibu bapa sangat penting bagi mengatasi masalah tingkah laku ponteng sekolah. Ibu bapa sendiri perlu memberi perhatian dengan mengambil tahu perkembangan pembelajaran anak- anak di sekolah. Sebagai contoh, ibu bapa perlulah menanyakan macam mana 
Nurul Farhana Mat Daud, Nur Asma Suzianti Mat Yusoff, Nurul Hazlin Mohd Azmi, Siti Zulaikha Khairunnisa Mohd Asri, Nur Zalikha Manisha Zaidi, Mohd Razimi Husin.

Kerja Sambilan Mempengaruhi Ketidakhadiran Pelajar Tingkatan 3.

Journal of Humanities and Social Sciences, vol. 3, no. 2, pp. 67-79, August 2021. DOI: 10.36079/lamintang.jhass-0302.240

pembelajaran anak-anak di sekolah setiap hari.

Peranan Pihak Sekolah

Sekolah merupakan institusi pengajian yang sepatutnya dihormati dan dinikmati oleh setiap individu yang menggunakan infrastruktur tersebut.

'Kalau dari segi pihak sekolah untuk menangani masalah ini yang pertama, pihak sekolah melalui unit disiplin akan memanggil budak tersebut ke bilik disipin untuk bagi nasihat dan 'warning', kata responden.

'Kedua, jika budak tersebut tiada perubahan, pihak sekolah akan rujuknya kepada unit Bimbingan dan Kaunseling untuk memberi nasihat dan program kepada mereka. Sekiranya tiada berubah, pihak sekolah akan mengumpulkan demerit kesalahan dia dan masuk kepada Lembaga Disiplin. Lembaga Disiplin akan mengadakan mesyuarat dan menjatuhkan hukuman apa-apa kepadanya. Mungkin dia akan dikenakan gantung, kena buang sekolah atau 'suggest' untuk tukar sekolah', kata responden.

''Okay itu dari segi pihak sekolah sebagai langkah. Maknanya, kita akan buat satu program. Bila kita buat macam ini, budak akan takut, "saya tidak boleh nak ponteng, nanti demerit saya cukup saya kena buang sekolah". Itulah yang pihak sekolah buat dan kenakan kepada murid-murid bermasalah, 'kata responden.

Menurut responden, langkah pihak sekolah ialah melalui unit disiplin yang akan memanggil pelajar ponteng sekolah ke bilik disiplin untuk memberikan nasihat dan amaran. Apabila pelajar tersebut tiada perubahan, pihak sekolah akan merujuk kepada unit Bimbingan dan Kaunseling untuk memberi nasihat dan program yang sepatutnya kepada mereka. Menurut responden, sekiranya pelajar tersebut masih lagi tiada perubahan, pihak sekolah akan mengumpulkan demerit kesalahan pelajar tersebut dan masuk kepada Lembaga Disiplin. Lembaga Disiplin akan mengadakan mesyuarat dan menjatuhkan hukuman yang sewajarnya kepada pelajar itu. Kemungkinan pelajar itu akan dikenakan gantung, buang sekolah atau cadangan untuk tukar sekolah lain.

\section{Peranan Media Massa}

Peranan media massa merupakan salah satu langkah yang boleh diambil bagi mengatasi masalah tingkah laku ponteng sekolah.

'Kalau dari media massa, mungkin boleh melakukan kempen kesedaran ataupun boleh mewujudkan satu benda yang menarik minat remaja. Contohnya, kempen kerjaya seperti kita kumpul budak-budak yang bermasalah ini, kita bawa pergi ke satu pameran unit kerjaya. Bila mereka tengok, mereka akan belajar bersungguh-sungguh sebab mungkin mereka boleh jadi cikgu, boleh jadi doktor. Itu adalah satu kesedaran kepada mereka, 'kata responden.

Menurut responden, pihak media massa boleh melakukan kempen kesedaran ataupun boleh mewujudkan satu benda yang menarik minat golongan remaja. Sebagai contoh, kempen kerjaya yang mengumpulkan pelajar yang bermasalah untuk dibawa ke pameran unit kerjaya. Apabila pelajar itu menghadiri pameran ini akan melahirkan semangat untuk mereka belajar bersungguh-sungguh menjadi seseorang yang berjaya pada masa akan datang. Selain itu, pihak media massa juga mestilah menyebarkan iklan-iklan nasihat dengan penerapan nilai-nilai moral supaya dapat memberi pengajaran kepada semua pihak terutamanya kepada golongan remaja.

\subsection{Kesan Masalah Ponteng Sekolah}

Kesan masalah tingkah laku ponteng sekolah kepada pelajar dan pihak sekolah., ialah:

Kesan kepada pelajar iaitu pelajar itu akan kerugian

Menurut responden, salah satu kesan masalah ponteng sekolah kepada pelajar ialah pelajar itu akan kerugian. 
Nurul Farhana Mat Daud, Nur Asma Suzianti Mat Yusoff, Nurul Hazlin Mohd Azmi, Siti Zulaikha Khairunnisa Mohd Asri, Nur Zalikha Manisha Zaidi, Mohd Razimi Husin.

Kerja Sambilan Mempengaruhi Ketidakhadiran Pelajar Tingkatan 3.

Journal of Humanities and Social Sciences, vol. 3, no. 2, pp. 67-79, August 2021. DOI: 10.36079/lamintang.jhass-0302.240

"Salah satu kesan kepada pelajar itu yang pertama membawa kesan rugi kepada pelajar itu sendiri. Mengapa saya kata merugikan sebab yang pertama dia tertinggal silibus," kata responden.

Hal ini dikatakan demikian kerana pelajar itu akan ketinggalan silibus pembelajaran. Pelajar itu akan ketinggalan dalam proses pembelajaran dan pengajaran yang digiatkan oleh guru di sekolah. Hal ini akan menyebabkan pelajar itu tidak faham mengenai setiap titik penting di dalam pelajaran sejajar dengan alasan tidak hadir ke sekolah. Akhirnya pelajar itu tidak dapat menjawab soalan peperiksaan dengan baik. Impaknya, pencapaian akademik pelajar itu akan merosot dan akhirnya menyumbang kepada kemerosotan pencapaian akademik sekolah. Bak kata pepatah, kerana nila setitik, susu rosak sebelanga. Kerana kesilapan pelajar itu sendiri, tompok hitam tercalit ke atas kertas putih pencapaian akademik sekolah.

\section{Kesan kepada pelajar iaitu sistem demerit akan bertambah}

Sistem demerit bertujuan untuk merekod kesalahan (demerit) dan sumbangan (merit) murid. Setiap perlanggaran disiplin ada markahnya begitu juga dengan sumbangan. Semua pengiraan markah dan analisis dilakukan oleh komputer. Pada awal tahun setiap murid dianugerahkan 40 markah yang perlu dijaga sepanjang tahun. Murid yang melakukan perlanggaran disiplin markahnya akan berkurangan dan sekiranya mereka memberi sumbangan markahnya akan bertambah. Setiap murid yang markah demeritnya telah berkurangan sehingga 10 akan diambil tindakan menghantar surat makluman kepada ibu bapa. Murid ini juga boleh dikenakan tindakan rotan. Tambahan bilangan rotan atau digantung persekolahan sekiranya markah sentiasa berkurangan sehingga kepada tindakan buang sekolah jika markah 40 tadi tidak berbaki lagi.

'Yang kedua, bila dia ponteng sekolah, Unit Disiplin akan bagi dia sistem demerit. Sistem dimerit maknanya setiap kesalahan yang pelajar buat kita akan catat dalam rekod dia. Sebagai contoh, kalau ponteng kita akan dimerit dia 5 mata. Jadi kita akan kumpul mata itu cukup 40 mata, kita akan gantung, cukup lagi 20 mata, kita akan buang. Ok tu kesan kepada murid itu sendiri. Jadi dia kena gantung, kena buang tak boleh sekolah, 'kata responden.

Menurut responden, apabila pelajar ponteng sekolah, Unit Disiplin akan bagi demerit kepada pelajar tersebut. Sebagai contoh, demerit kesalahan ponteng ialah 5 mata. Unit Disiplin akan mengumpul mata kesalahan demerit itu. Apabila mata kesalahan demerit pelajar tersebut sudah cukup 40 mata, dia akan digantung sekolah oleh pihak sekolah dan dibuang sekolah apabila mata kesalahan demerit dia bertambah lagi 20 mata.

\section{Kesan kepada pihak sekolah}

Menurut responden, antara kesan masalah tingkah laku ponteng sekolah kepada pihak sekolah ialah menjejaskan prestasi akademik iaitu gred sekolah akan menurun kerana pelajar tidak fokus ketika guru sedang mengajar sehingga menyebabkan pelajar tidak dapat menjawab peperiksaan kerana dia tertinggal silibus.

'Kesan kepada sekolah yang pertama ialah mencemarkan nama sekolahlah kan. Maknanya kalau pihak polis tangkap, dia akan Tanya "awak sekolah dekat mana" jadi polis itu dapat 'detect'lah sekolah Kepong, 'kata responden.

'Yang kedua menjejaskan prestasi akademik, maknanya markah gred ataupun gredlah, ok gred purata sekolah akan menurun sebab apa sebab budak tak focus dan 'exam' tak boleh nak buat, jadi dia dah tertinggal silibus dia tak boleh buat 'exam',kata responden.

Itulah kesan kepada sekolah. Perkara ini menyebabkan peratusan gred sekolah menurun dalam kalangan sekolah-sekolah lain. Pihak sekolah terpaksa menjawab dengan pihak atasan disebabkan gred peratusan sekolah yang menurun. Menurut responden, apabila pelajar ponteng sekolah tetapi dia telah ditangkap oleh pihak polis ia akan mencemarkan nama sekolah. Hal ini dikatakan demikian kerana pihak polis akan bertanya 'awak sekolah dekat mana'. Perkara ini mencemarkan nama sekolah kerana 
pihak polis dapat mengetahui murid sekolah mana yang ponteng.

\section{Perbincangan}

Mengikut teori maslow yang diperkembangkan oleh Abraham Maslow pada tahun 1943 dalam kertas kerjanya $A$ theory of Human Motivation dalam jurnal Scientific Psychological Review [8]. Dalam teori Maslow terdapat lima peringkat keperluan manusia iaitu yang pertama kepeluan asas, kedua keperluan keselamatan dan jaminan diri, ketiga keperluan untuk berkasih sayang, keempat keperluan untuk penghormatan diri dan yang terakhir ialah keperluan untuk pencapaian diri. Bila satu keperluan dicapai, keperluan yang seterusnya akan menjadi satu keperluan atau keutamaan seterusnya. Setiap individu akan memastikan tahap keperluan terendah dipenuhi terlebih dahulu sebelum berusaha untuk memenuhi keperluan tahap yang lebih tinggi. Merujuk kepada teori ini kanak-kanak kebanyakkan akan mencuba apa sahaja untuk mendapatkan keperluan yang mereka inginkan terutamanya keperluan untuk pencapaian diri. Menurut Maslow [8] tingkat memenuhi keperluan diri ini adalah mengikut susunan secara berhierarki. Hal ini adalah, untuk memenuhi satu hierarki keperluan di atas, seseorang perlu memenuhi hierarki keperluan yang terdahulu. Ini bermakna, seseorang itu tidak mungkin dapat memenuhi keperluan tingkat atas terlebih dahulu tanpa memenuhi tingkat keperluan di bawah.

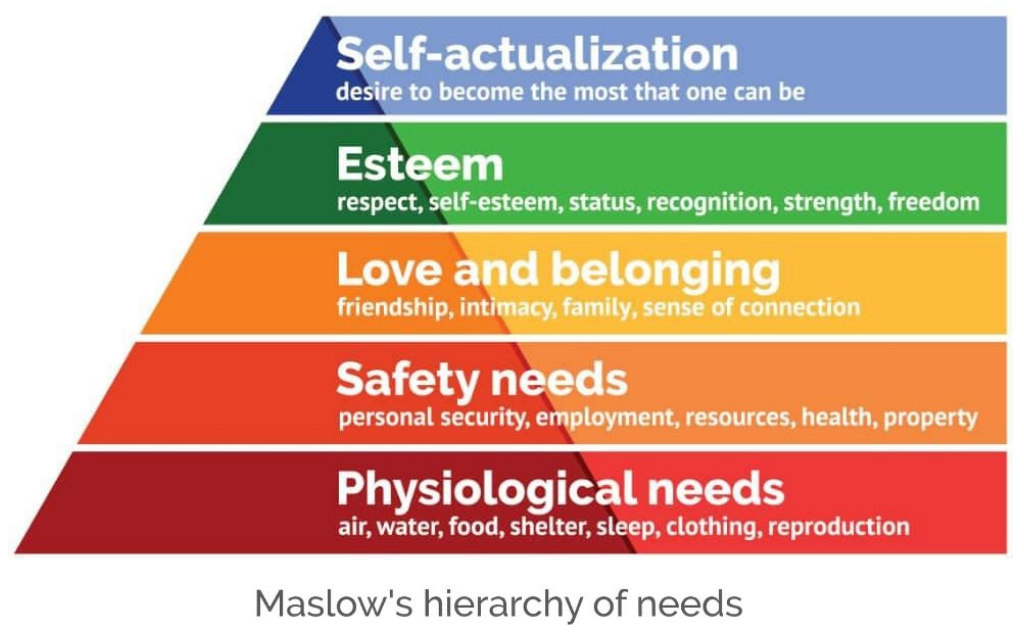

Rajah 1. Hierarki Keperluan Maslow [8]

Rajah 1 menunjukkan tentang kelima-lima keperluan yang dinyatakan dalam teori Maslow. Keperluan yang pertama adalah keperluan asas. Peringkat ini merupakan keperluan yang paling asas. Keperluan ini adalah penting bagi sessuatu organisme, apatah lagi manusia. Keperluan asas ini merangkumi apa yang diperlukan untuk diri atau fizikal seseorang seperti keperluan mendapatkan makanan, minuman dan tempat tinggal. Keperluan kedua pula adalah keperluan keselamatan dan jaminan diri. Pada peringkat ini merupakan keperluan keselamatan peribadi, keselamatan kewangan, kesihatan dan tidak akan menjadi mangsa penyalahgunaan kuasa. Seterusnya, keperluan ketiga iaitu keperluan untuk berkasih sayang. Inilah keperluan manusia untuk dicintai dan merasai perasaan "kekitaan". Semua pekerja perlu merasai bahawa mereka diperlukan dan mempunyai peranan tersendiri di dalam organisasi. Jika dipenuhi, perasaan ketegangan dan tekanan (stress) di kalangan pekerja dapat dielakkan atau dikurangkan. Selain itu, keperluan keempat iaitu keperluan untuk penghormatan diri. Keperluan ini ada kaitan dengan keperluan pekerja untuk diormati dan diberi peluang menghormati orang lain. Beri mereka tugas yang boleh memberi mereka peluang untuk memberi sumbangan. Ini akan meningkatkan penghormatan diri. Keperluan kelima yang merupakan keperluan terakhir iaitu keperluan untuk pencapaian diri. Keperluan ini berkaitan dengan keperluan untuk mencapai cita-cita diri sendiri mengikut potensi seseorang manusia (pekerja). Berdasarkan teori ini, Maslow telah membahagikan lima keperluan kepada dua kategori iaitu tahap tinggi iaitu keperluan untuk berkasih sayang, penghormatan diri dan pencapaian diri manakala tahap rendah iaitu keperluan 
asas dan keselamatan.

Seperti keputusan dapatan kajian dari hasil temu bual, faktor kerja sambilan ialah faktor utama sekali dalam masalah ponteng di sekolah. Hal ini dapat dilihat apabila responden menyatakan bahawa pelajar yang melakukan masalah ponteng adalah disebabkan mereka bekerja sambilan. Keadaan ini telah menyebabkan mereka merasa sangat mengantuk dan penat ketika hadir ke sekolah dan juga boleh menyebabkan mereka tidak hadir ke sekolah. Jika merujuk kepada teori Maslow, faktor kerja sambilan berkait dengan keperluan asas dan keperluan pencapaian diri. Hal ini dikatakan sedemikian kerana pelajar yang membuat kerja sambilan adalah bertujuan untuk memenuhi keperluan asas dirinya seperti makanan dan minuman untuk kehidupan harian manakala ianya juga kerana pelajar tersebut menginginkan pencapaian hidup dengan mempunyai pekerjaan biarpun pekerjaan itu bukanlah kerjaya yang lebih baik. Menurut Haiman [6], jika pekerjaan telah memenuhi beberapa keperluan yang lebih tinggi maka hal tersebut akan menentukan dalam motivasi kerja. Tingkat aspirasi sangat berhubungan erat dengan hierarki keperluan, dan sikap akan menentukan jalan yang akan ditempuh seseorang untuk pencapaian keperluannya.

Selain itu, keputusan dapatan kajian dari hasil temu bual juga mendapati faktor latar belakang keluarga adalah faktor kedua dalam masalah ponteng sekolah. Hal ini dapat dilihat apabila responden menyatakan bahawa pelajar yang melakukan masalah ponteng adalah disebabkan oleh latar belakang keluarga yang bermasalah. Keadaan ini menyebabkan pelajar sangat stress dekat rumah. Hal ini berlaku kerana disebabkan oleh mak ayah bercerai dan mak ayah yang bergaduh. Apabila berlakunya hal-hal sebegini, pelajar tidak boleh focus dalam pembelajaran apabila dating ke sekolah. Jika merujuk kepada teori Maslow, faktor latar belakang keluarga berkait dengan keperluan untuk berkasih sayang. Hal ini dikatakan sedemikian kerana masalah keluarga menyebabkan pelajar tidak mendapat keperluan kasih sayang daripada keluarga.

\section{Rumusan}

Ponteng sekolah merupakan satu masalah disiplin yang semakin serius dikalangan pelajar sekolah menengah. Masalah-masalah disiplin yang lain akan timbul sekiranya masalah ponteng ini tidak dibendung dan dikawal. Hal ini dikatakan sedemikian kerana pelajar yang ponteng akan menggunakan masa tersebut dengan melibatkan diri dalam perkara-perkara yang tidak senonoh. Mereka akan diperalatkan oleh kumpulan anasir-anasir yang jahat. Apabila mereka telah terjebat dalam kumpulan anasir-anasir jahat tersebut, mereka akan melibatkan diri dalam kes-kes mengedar dadah, mencuri dan sebagainya. Masalah ponteng ini akan memberi kesan dan impak yang negatif terhadap diri, keluarga, masyarakat, dan masa depan pelajar itu sendiri. Berdasarkan temu bual yang dilakukan, responden menyatakan bahawa faktor masalah keluarga adalah merupakan faktor utama yang mempengaruhi pelajar terlibat dalam masalah ponteng sekolah. Hal ini dikatakan sedemikian kerana masalah keluarga yang dihadapi oleh seseorang pelajar tersebut menyebabkan mereka berasa tertekan dengan masalah yang dihadapi dan keadaan ini juga menyebabkan mereka memang tidak seronok untuk datang ke sekolah.

Selain itu, faktor rakan sebaya yang menyebabkan pelajar tidak hadir ke sekolah. Hal ini kerana pengaruh rakan sebaya yang mengajak rakan-rakannya untuk sama-sama tidak hadir ke sekolah kerana hendak melepak di luar-luar sekolah dan di pusat membeli belah. Golongan muda merupakan aset negara di mana mereka bakal menjadi pelapis tampok

kepimpinan negara kelak. Oleh itu, sudah menjadi kemestian untuk memastikan golongan muda ini dibentuk supaya mempunyai tahap intelek dan sahsiah yang cemerlang agar dapat memberi manfaat kepada negara pada masa hadapan. Sekiranya golongan ini gagal dibentuk untuk menjadi insan yang berkualiti, negara Malaysia akan menghadapi masalah yang besar pada masa akan datang. Oleh itu, kajian perlu dijalankan untuk mengenal pasti dan mengetahui faktor utama yang menyebabkan gejala pelajar ponteng sekolah. Dengan mengetahui faktor penyebab gejala ponteng boleh membantu semua pihak dalam menangani permasalahan ini dari terus menular.

\section{Rujukan}

[1] Anynomous, Kamus Dewan (Edisi Ketiga). Kuala Lumpur: Dewan Bahasa dan Pustaka, 1991.

[2] A. S. Yahya, Mengurus Disiplin Pelajar. Bentong, Pahang: PTS Professional Pub, 2005.

[3] J. A. J. Eing, Pengurusan Disiplin Murid. Kuala Lumpur: PTS Professional, 2007.

[4] A. Yahya, S. Hashim, Y. Boon, H. L. Chan, "Faktor-Faktor Yang Mempengaruhi Gejala 
Ponteng di Kalangan Pelajar Sekolah Menengah Johor," Journal of Science \& Mathematics Education. pp. 1-20, 2007.

[5] L. H. M. Amin, M. R. A. Hafiz, M. N. A. Kamarulzalis, A. H. Ibrahim, N. M. Taib, N. H. Ramlan, M. R. Husin, "Masalah Kecelaruan Tingkah Laku: Ponteng Sekolah", International Journal of Humanities, Management and Social Science, vol. 2, no. 1, pp. 51-64, Jun. 2019. https://doi.org/10.36079/lamintang.ij-humass-0201.22

[6] J. Hassan, and N. S. Muhammad, Faktor-Faktor Yang Menyebabkan Masalah Ponteng Sekolah di Sekolah Menengah Daerah Kulaijaya Johor. Johor: Universiti Teknologi Malaysia. pp. 1-11, 2010.

[7] N. M. Nor, A. Hamzah, dan N. F. Junus, "Faktor-faktor Yang Mempengaruhi Gejala Ponteng di Kalangan Pelajar Sekolah Menengah Kebangsaan Taman Selesa Jaya 2 Skudai", Journal of Educational Psychology \& Counseling, Vol. pp. 12-29, 2012.

[8] A. H. Maslow, "A theory of human motivation," Psychological Review, vol. 50, no. 4, pp. 370396. https://doi.org/10.1037/h0054346

[9] R. Masri, A. Ahmad, and R. A. Rani, "Teori Maslow dalam Konteks Memenuhi Keperluan Asas Pekerja dan Peranannya dalam Meningkatkan Prestasi Organisasi: Kajian Dan Perspektif Islam," Jurnal Hadhari, vol. 10, no. 1, pp. 1-27, 2018.

[10] H. B. A. Kalam. Pengaruh Persekitaran Sosial Terhadap Tingkah Laku Disiplin Murid Sekolah Rendah di Klang, Selangor. (Tesis Sarjana). Selangor: Universiti Putra Malaysia, 2016.

[11] A. Bandura, "Self-efficacy: Toward a Unifying Theory of Behavioral Change," Psychological Review, vol. 84, no. 2, pp. 191-215, 1997. https://doi.org/10.1037/0033-295X.84.2.191

[12] K. Zainal, "Memahami Tingkah Laku Remaja Bermasalah dari Perspektif Teori Tingkah Laku, Humanistik, Psikoanalitik \& Tret Personaliti," Jurnal Pengajian Umum, vol. 9, no. 4, pp. 4356, 2008.

[13] N. Ali, R. Yusuf and H. Ali, "Pola Bekerja Sambilan Kalangan Pelajar Sekolah Menengah Di Daerah Melaka Tengah dan Implikasinya Terhadap Prestasi Pembelajaran di Sekolah," Jurnal e-Bangi, vol. 3, no. 1, pp. 1-12, 2017.

[14] A. R. A. Rashid, S. Hussin and J. Tubah, Institusi Keluarga Menghadapi Cabaran Alaf Baru. Kuala Lumpur: Utusan Publications, 2006.

[15] M. A. A. Bakar, Perkaitan antara Hubungan Keluarga, Pengaruh Rakan Sebaya dan Kecerdasan Emosi dengan Tingkah Laku Pelajar. Johor: Universiti Teknologi Malaysia, 2007.

[16] F. S. Haiman, Religious Expression and the American Constitution. Michigan: Michigan State University Press, 2003. 